\title{
Influence of Substrate Temperature and Magnesium Content on Morphology Evolution and Luminescence of Mg-doped $\mathrm{ZnO}$ Films
}

\author{
D.V. Myroniuk*, L.A. Myroniuk, V.A. Karpyna, L.I. Petrosian, A.I. Ievtushenko
}

\author{
I.M. Frantsevich Institute for Problems in Materials Science, 3, Krzhyzhanovsky St., 03142 Kyiv, Ukraine
}

(Received 16 June 2021; revised manuscript received 20 October 2021; published online 25 October 2021)

\begin{abstract}
Results of studies by scanning electron microscopy and photoluminescence (PL) of structural features and radiative transitions of $\mathrm{ZnO}: \mathrm{Mg}$ films grown by atmospheric pressure metal-organic chemical vapor deposition (APMOCVD) on silicon substrates are presented. Different ZnO:Mg microstructures from polycrystalline films with smooth morphology to columns and hexagonal rods are effectively formed in a wide temperature range $190-450{ }^{\circ} \mathrm{C}$ using two compositions of a mixture of zinc and magnesium (5 and 10 wt. \%) acetylacetonates (ZnAA and MgAA, respectively) as precursors. The substrate temperatures have a drastic effect on the crystallinity and morphology of $\mathrm{ZnO}$ films. A column shaped $\mathrm{ZnO}$ microstructure is formed at a substrate temperature above $350{ }^{\circ} \mathrm{C}$. The $\mathrm{MgAA}$ content in the mixture of precursors also affects the morphology of polycrystalline films. At lower substrate temperatures $\left(200-320^{\circ} \mathrm{C}\right)$, grown $\mathrm{ZnO}: \mathrm{Mg}$ samples with MgAA content of $10 \mathrm{wt}$. \% have a surface morphology characterized by enlarged grains compared to samples grown with MgAA 5 wt. $\%$, whereas high substrate temperatures $\left(350-450{ }^{\circ} \mathrm{C}\right)$ promote to form a surface morphology with rod-like structures in both cases: 5 and $10 \mathrm{wt}$. \% of MgAA content. The growth rate of $\mathrm{ZnO}$ structures increases with increasing substrate temperatures. The PL emission spectra of samples with 10 wt. \% MgAA demonstrate increased near band edge (NBE) emission and suppress defect level emission compared to samples with $5 \mathrm{wt}$ \% MgAA. Therefore, we can conclude that magnesium acts as an isoelectronic impurity improving NBE PL emission due to gettering of defects. Mg also causes an increase in grain size, improving the crystalline perfection of $\mathrm{ZnO}: \mathrm{Mg}$ polycrystalline films grown at low substrate temperatures, as well as helps to grow hexagonal rods at higher substrate temperatures. Thus, $\mathrm{Mg}$-doped $\mathrm{ZnO}$ microstructures grown in the high temperature range could be an effective photocatalyst.
\end{abstract}

Keywords: Atmospheric pressure metalorganic chemical vapor deposition, Zinc acetylacetonate, Magnesium acetylacetonate, Scanning electron microscope, Photoluminescence.

DOI: 10.21272/jnep.13(5).05008

PACS numbers: 68.55.J -, 78.55.Et

\section{INTRODUCTION}

Zinc oxide has a band gap of $3.37 \mathrm{eV}$ at room temperature (RT), which makes it one of the most interesting candidate materials for optoelectronic devices in the ultraviolet (UV) region [1]. The large exciton binding energy of about $60 \mathrm{meV}$ provides pronounced excitonic effects in the emission and absorption spectra up to RT [2]. Due to its physical properties, wide band gap zinc oxide is a promising photocatalytic material that may become a cheap alternative to existing photocatalysts based on $\mathrm{TiO}_{2}$ for the degradation of organic pollutants in the future [3]. On the other hand, the key point of semiconductor devices is to design heterostructures that can provide the development of high electron mobility transistors and light emission diodes. It is critical to have band gap engineering in order to realize a device-based material [4]. Band gap engineering of $\mathrm{ZnO}$ can be realized by alloying with $\mathrm{MgO}$ and $\mathrm{CdO}$. Theoretically, the band gap of $\mathrm{MgZnO}$ ternary alloys can vary from $3.37 \mathrm{eV}(\mathrm{ZnO})$ to $7.8 \mathrm{eV}(\mathrm{MgO})$ [5]. Nonetheless, a high $\mathrm{MgO}$ content leads to phase separation. For a moderate content of $\mathrm{MgO}$, the alloy keeps the wurtzite crystal structure of $\mathrm{ZnO}$, providing a wide range of direct band gap engineering ranging from 3.37 to $4.0 \mathrm{eV}$ [6]. In addition, the exciton binding energy increases in $\mathrm{ZnMgO} / \mathrm{ZnO} / \mathrm{ZnMgO}$ quantum wells due to an increase in carrier confinement [7], thus making this heterostructure suitable for fabricating electronic LED devices.
Many techniques can be used for the preparation of $\mathrm{ZnO}$ films, such as molecular beam epitaxy [8], pulse laser deposition [6,9], direct current [10] and radio frequency magnetron sputtering [11], hydrothermal [12], chemical bath deposition [13], sol-gel spin coating [14], spray pyrolysis [15] and metal organic vapor phase epitaxy (MOCVD) [16-18]. The last one allows to change the deposition parameters, respectively, to control the growth rate and morphology of $\mathrm{ZnO}$ structures, and to influence the photocatalytic activity [16]. The advantage of this method is the possibility to deposit coatings on large surfaces, a high deposition rate with the ability to control atomic composition for mass production. The authors of [16] discovered the formation of nanostructures with multilayer tower and rod-shaped configurations at a substrate temperature in the range from 300 to $475{ }^{\circ} \mathrm{C}$. However, they provided information only for pure $\mathrm{ZnO}$.

In this work, we present the possibilities of obtaining $\mathrm{ZnO}: \mathrm{Mg}$ structures with different shapes and dimensions by means of modified MOCVD method called APMOCVD, i.e., atmospheric pressure MOCVD. By changing the temperature and composition of $\mathrm{Zn}$ and $\mathrm{Mg}$ precursors, we study the evaluation of morphology and photoluminescence behavior of $\mathrm{ZnO}: \mathrm{Mg}$ structures grown by APMOCVD.

\section{EXPERIMENTAL DETAILS}

Mg-doped $\mathrm{ZnO}$ films were deposited by APMOCVD

\footnotetext{
*denysmyroniuk@gmail.com
} 
on silicon substrates in $190-450{ }^{\circ} \mathrm{C}$ temperature range using the mixture of zinc and magnesium acetylacetonates (ZnAA and MgAA, respectively) as precursors.

Scanning electron microscope (SEM) was chosen to investigate the morphology of $\mathrm{Mg}$-doped $\mathrm{ZnO}$ structures depending on substrate temperatures. The microstructure of $\mathrm{ZnO}: \mathrm{Mg}$ samples was studied by a Leo 1550 Gemini SEM at a primary beam acceleration potential of $5 \mathrm{kV}$.

The photoluminescence (PL) measurements were carried out at $\mathrm{RT}$ with a solid-state laser operating in
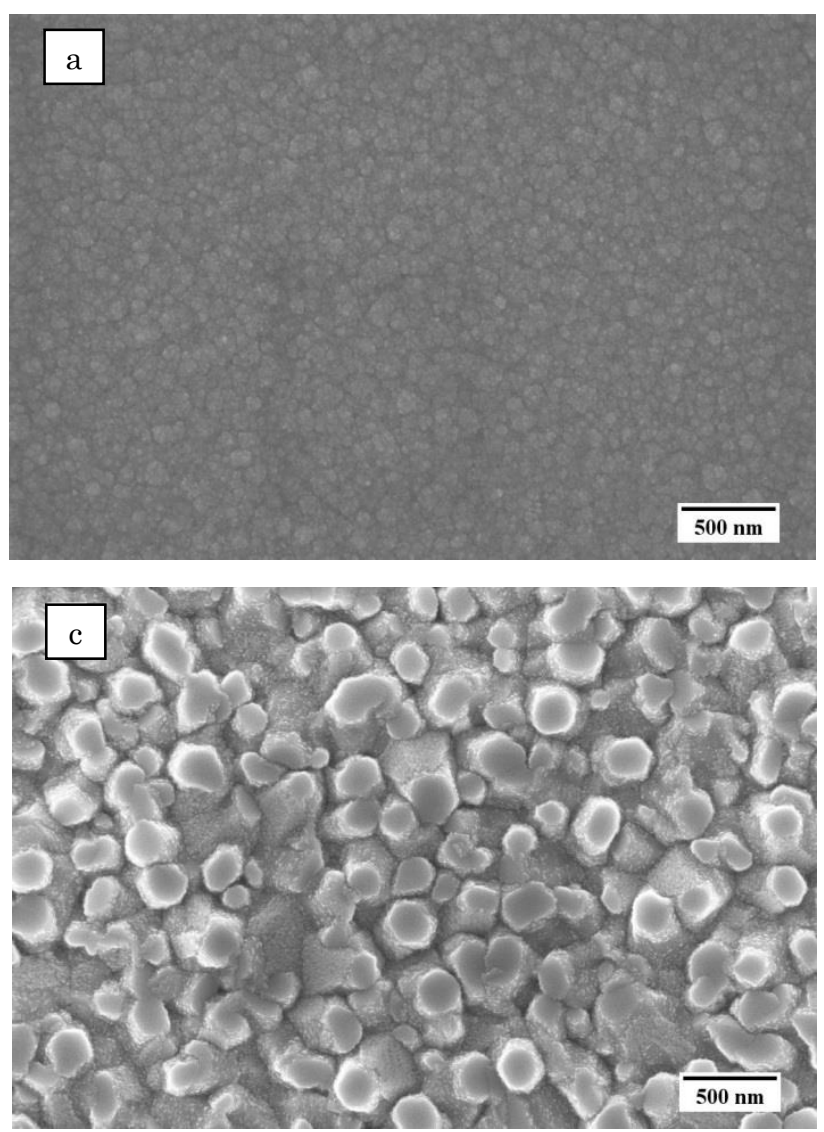

the UV range. The luminescence was collected and mirrored into a monochromator equipped with a $\mathrm{Si}$ CCD detector (2D-matrix of 2000/800 pixels), cooled with liquid nitrogen, whose spectral resolution was around $0.1 \mathrm{meV}$.

\section{RESULTS AND DISCUSSION}

ZnO:Mg (ZnAA + MgAA 5 wt. \%) (Fig. 1) and (ZnAA + MgAA 10 wt. \%) (Fig. 2) films were grown on Si (100) substrates at temperatures from 250 to $420^{\circ} \mathrm{C}$.
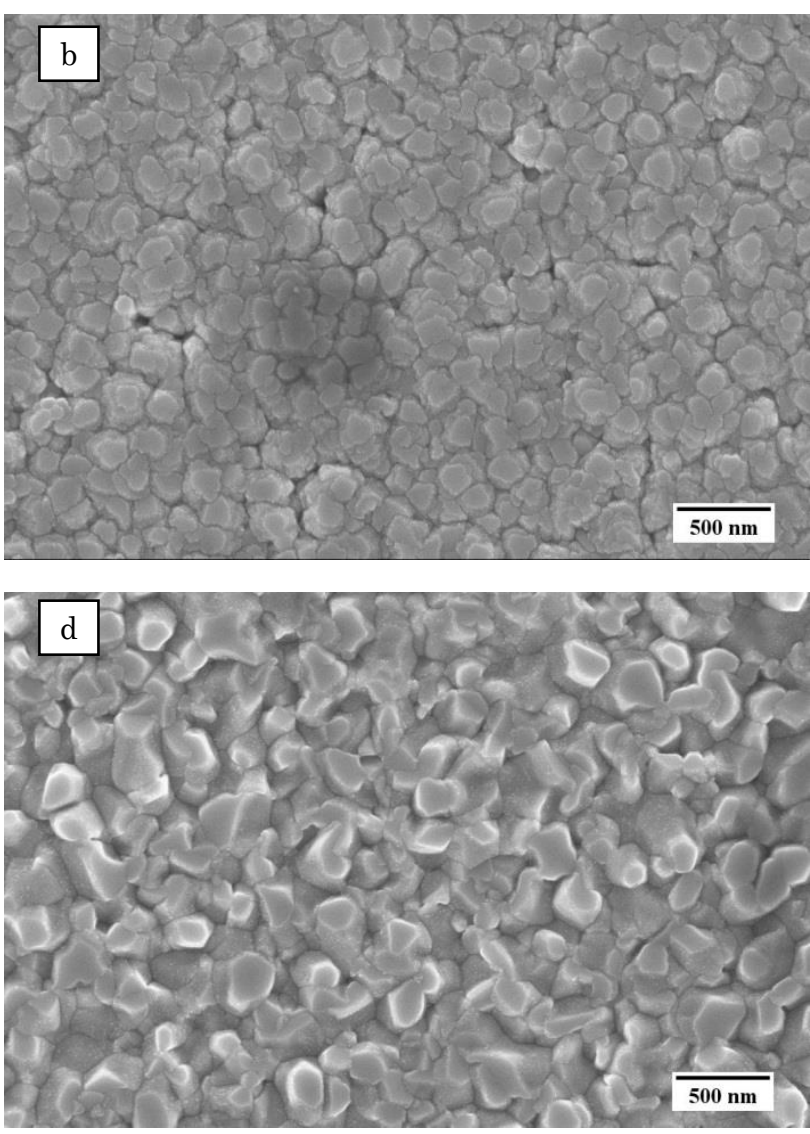

Fig. 1 - SEM images of ZnO:Mg (ZnAA + MgAA 5 wt. \%) structures obtained at different deposition temperatures: (a) $250{ }^{\circ} \mathrm{C}$, (b) $315{ }^{\circ} \mathrm{C}$, (c) $350{ }^{\circ} \mathrm{C}$, (d) $390^{\circ} \mathrm{C}$

As one can see, the surface morphology of $\mathrm{ZnO}: \mathrm{Mg}$ structures changes with increasing substrate temperature and MgAA content in the grown samples (Fig. 1 and Fig. 2).

In the case of $\mathrm{ZnO}: \mathrm{Mg}(\mathrm{ZnAA}+\mathrm{MgAA} 5$ wt. \%) films deposited at low substrate temperatures $\left(250-300{ }^{\circ} \mathrm{C}\right)$, the mobility of adatoms is low, and the bases of $\mathrm{ZnO}$ wurtzite columns retain a random orientation, which together form a multigrain layer. The grain size increases with increasing substrate temperature from about $75 \mathrm{~nm}$ (Fig. 1a) to 100-150 nm (Fig. 1b). When the substrate temperature reaches $350-400{ }^{\circ} \mathrm{C}$, both the mobility of adatoms and intergranular diffusion increase significantly, leading to the formation of a polycrystalline structure with a predominant orientation of crystallites in the (001) direction, i.e., perpendicular to the substrate, which is clearly visible at a substrate temperature of $350^{\circ} \mathrm{C}$ (Fig. 1c) and, as can be seen, structures are formed with a clear hexagonal cut. As a result of a further increase in temperature and intensification of the processes of diffusion and coalescence, there is a further increase in the structure with the formation of rods (Fig. 1d).

The kinetics and mechanism of the formation of self-organized structures is a complex and multi-stage process. It can be argued that their formation is a consequence of spontaneous adsorption and evaporation of adsorbate particles upon contact of the vapor phase with the surface of the solid substrate. The stage of the formation of two-dimensional clusters, their origin or nucleation is important. It is associated with a certain migration of adatoms (unattached atoms) and their coalescence. In the implementation of layered homoepitaxy by the Frank-Van der Merwe growth mechanism, the formed two-dimensional clusters grow and merge with each other forming a continuous monolayer. Volmer-Weber heteroepitaxy is associated with the formation of three-dimensional individual structures of 
nuclei on the substrate surface. An intermediate link between the above two methods is the StranskiKrastanov nucleation mechanism, which provides for the formation of the so-called wetting layer with the subsequent growth of pyramidal structures due to the removal of elastic deformations [19]. Observation of the surface demonstrates this method of forming hexagonal columns from the initial single formations of crystalline grains with a hexagonal shape of the order of 200$500 \mathrm{~nm}$.

SEM images of $\mathrm{ZnO}: \mathrm{Mg}$ ( $\mathrm{ZnAA}+\mathrm{MgAA} 10$ wt. \%) films (Fig. 2) also show the formation of large polycrystalline structures at $250{ }^{\circ} \mathrm{C}$ with grain sizes up to $800 \mathrm{~nm}$, of an arbitrary (non-hexagonal) shape, which overlap and compete with each other. At temperatures
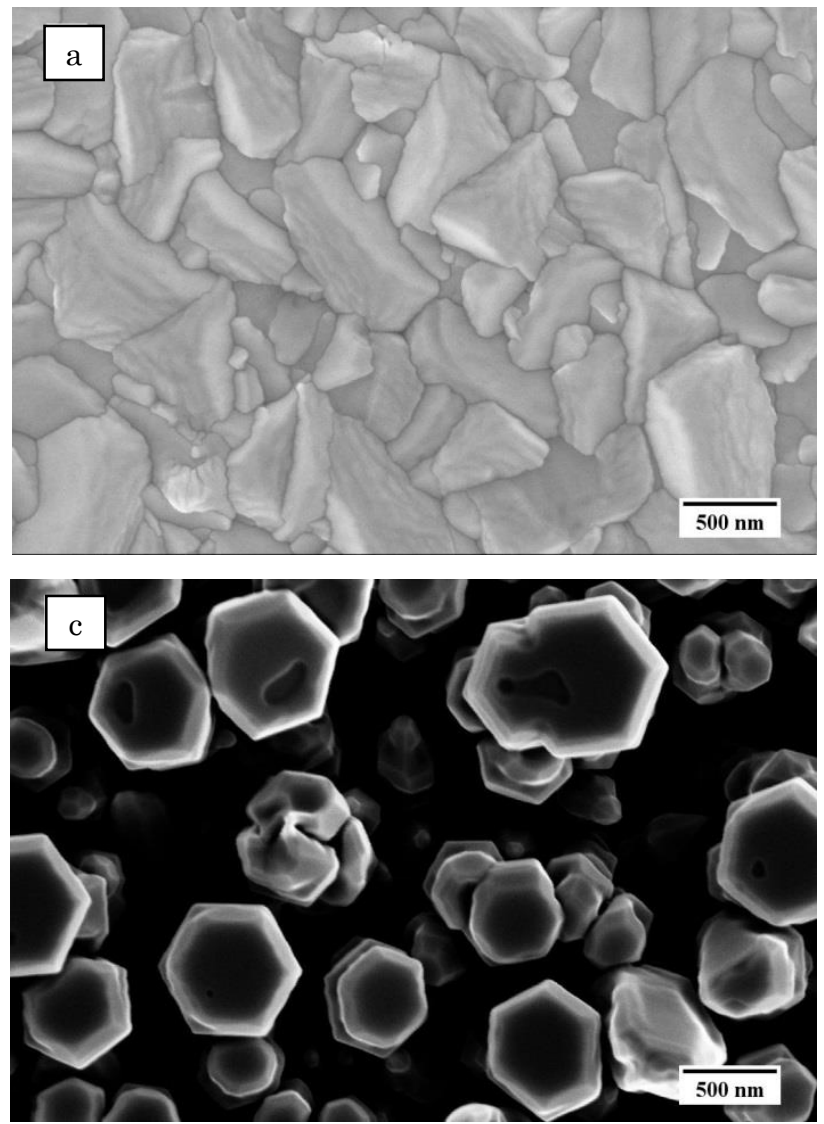

of $300-350^{\circ} \mathrm{C}$, the surface morphology of the samples takes the ordered form of hexagonal grains with a diameter of about $850 \mathrm{~nm}$ (Fig. 2b). In Fig. 2c, it is shown that columns already have a clear hexagonal shape. Diameters of hexagons are about $800 \mathrm{~nm}$, while the tip has a size of about $200 \mathrm{~nm}$. The image of the sample grown at a substrate temperature of $420^{\circ} \mathrm{C}$ (Fig. $2 \mathrm{~d}$ ) shows a quasi-array of well-formed hexagonal rods with a diameter of 200-300 $\mathrm{nm}$.

Comparing $\mathrm{ZnO}: \mathrm{Mg}$ structures grown at different concentrations of magnesium, we can conclude that an increase in the concentration of magnesium acetylacetonate in the precursor from 5 to $10 \mathrm{wt}$ \% creates conditions for the growth of $\mathrm{ZnO}-\mathrm{Mg}$ rods, especially with increasing substrate temperature.
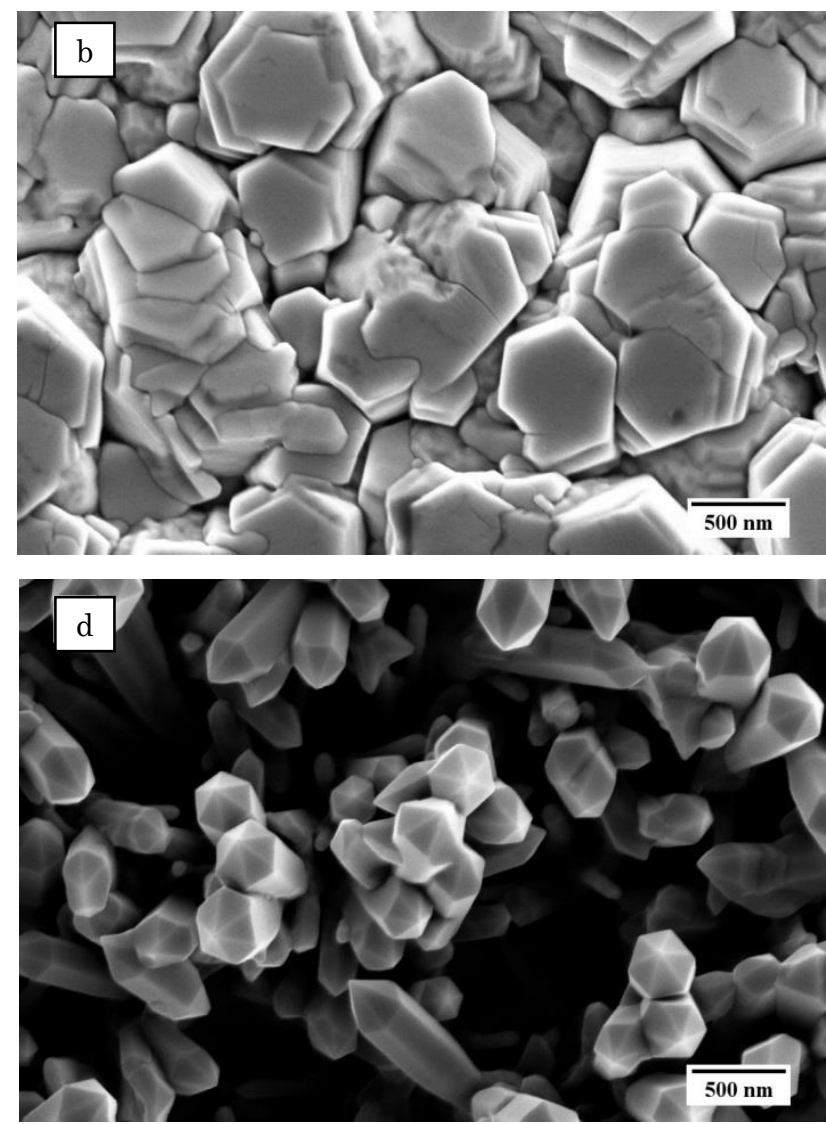

Fig. 2 - SEM images of $\mathrm{ZnO}: \mathrm{Mg}$ (ZnAA + MgAA $10 \mathrm{wt}$ \%) nanostructures obtained at different deposition temperatures: (a) $250^{\circ} \mathrm{C}$, (b) $315^{\circ} \mathrm{C}$, (c) $350{ }^{\circ} \mathrm{C}$, (d) $390^{\circ} \mathrm{C}$

Fig. 3 presents SEM images of the cross section of $\mathrm{ZnO}: \mathrm{Mg}$ structures. It is shown that the grain size and film thickness of $\mathrm{ZnO}: \mathrm{Mg}$ increase to a certain value with increasing temperature. The reason for the formation of the film at the initial stage of the process is the low growth temperature, i.e., atoms and molecules that settle on the surface of the substrate do not have enough kinetic energy to move to the appropriate position, where they join together to form larger grains. With increasing substrate temperature to $\sim 300{ }^{\circ} \mathrm{C}$, in Fig. $3 b$ we observe a columnar structure. The film is rough and homogeneous with a thickness of $\sim 700 \mathrm{~nm}$. At a substrate temperature of $\sim 400{ }^{\circ} \mathrm{C}$, the film thickness is about $1.5 \mu \mathrm{m}$ (Fig. $3 \mathrm{~d}$ ).

As the substrate temperature increases, the for- mation of zinc oxide molecules accelerates and the process of nucleation and crystallization of new grains decreases, as a consequence, the growth rate of separated structures increases [17].

In the case of increasing the concentration of the initial precursor of $\mathrm{MgAA}$ to $10 \mathrm{wt}$. \% in a relatively high temperature range $\left(350-400{ }^{\circ} \mathrm{C}\right)$, nanostructures grow in the form of rods with a hexagonal pointed pyramidal top (Fig. 3h). In addition, the thickness of these films is greater and is more than $2 \mu \mathrm{m}$.

The morphology analysis of the formed films and structures allows us to conclude that the formation of the film and the growth of structures depend on the mass of the precursor, which slowly evaporates. The greater the mass of the precursor or the closer the sub- 
strate is to the evaporation zone of the precursor, the greater the film thickness. Structures are formed mainly by the Stranski-Krastanov mechanism, but when the vapor pressure above the substrate decreases and at a
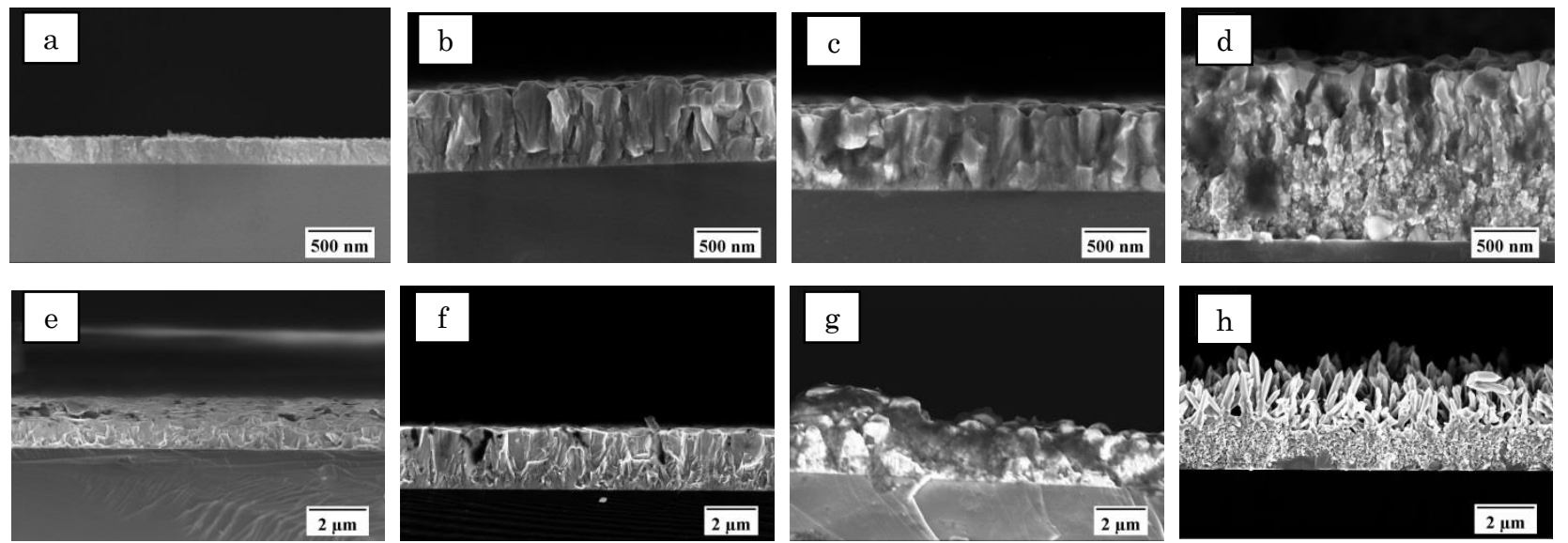

Fig. 3 - Cross-section view of $\mathrm{ZnO}: \mathrm{Mg}$ structures obtained at different deposition temperatures: a-d (ZnAA + MgAA 5 wt. \%) (a) $250{ }^{\circ} \mathrm{C}$, (b) $315^{\circ} \mathrm{C}$, (c) $350{ }^{\circ} \mathrm{C}$, (d) $390^{\circ} \mathrm{C}$; e-h (ZnAA + MgAA 10 wt. \%) (e) $250{ }^{\circ} \mathrm{C}$, (f) $320^{\circ} \mathrm{C}$, (g) $350{ }^{\circ} \mathrm{C},(\mathrm{h}) 420{ }^{\circ} \mathrm{C}$
The main characterization technique to be used for $\mathrm{ZnO}$ structures is $\mathrm{PL}$ spectroscopy. In this technique, a UV laser $(325 \mathrm{~nm})$ is used to excite the sample. As a result, the photon emission with different wavelengths, the so-called near band edge (NBE) emission and deep level emission (DLE), is observed (Fig. 4).

Fig. 4 shows the measured at RT PL spectra of $\mathrm{ZnO}: \mathrm{Mg}$ (ZnAA + MgAA 5 wt. \%) samples grown on silicon substrates in the temperature range $190-450{ }^{\circ} \mathrm{C}$. The spectra show a sharp peak at $377 \mathrm{~nm}$, which is attributed to the NBE emission of $\mathrm{ZnO}$ originated from free exciton recombination. The radiation band in the visible wavelength range (peak at $\sim 470 \mathrm{~nm}$ ) occurs due to radiative recombination (DLE) due to point defects in the $\mathrm{ZnO}$ lattice, such as oxygen vacancy, zinc vacancy, oxygen and zinc in interstitials $[4,20]$. However, the identification of recombination centers and mechanisms responsible for the luminescent properties is still controversial. It should be noted that $\mathrm{Mg}$ does not have a significant effect on the PL spectrum (there is no significant blue shift of the emission maximum). This may indicate that $\mathrm{Mg}$ is not fully incorporated (5 wt. \% of MgAA in the precursor mixture) in the cationic sublattice of $\mathrm{Zn}$.

Fig. 5 shows the RT PL spectra of $\mathrm{ZnO}: \mathrm{Mg}(\mathrm{ZnAA}+$ MgAA 10 wt. \%) samples deposited on silicon substrates in the temperature range $190-450{ }^{\circ} \mathrm{C}$. The results are similar to those described above. However, it should be noted that the use of 10 wt. \% MgAA in the precursors mixture (instead of $5 \mathrm{wt}$. \%) leads to an increase in the intensity of the marginal emission in the UV region of the spectrum and the suppression of defective emission in the blue-green region of the spectrum. It is also seen that the highest intensity of the marginal emission is demonstrated by samples deposited at $420-450{ }^{\circ} \mathrm{C}$. This may be due to the optimal quantum constraint associated with the geometry and size of nanorods (see Fig. $2 \mathrm{~d}$ and Fig. 3h). The high and sharp maximum is located approximately at a wavelength of $378 \mathrm{~nm}$ $\left(E=4.135 \times 10^{-15} \mathrm{eV} \cdot \mathrm{s}\right)$. temperature sufficient to activate the diffusion mechanism, the structures grow according to the VolmerWeber mechanism.

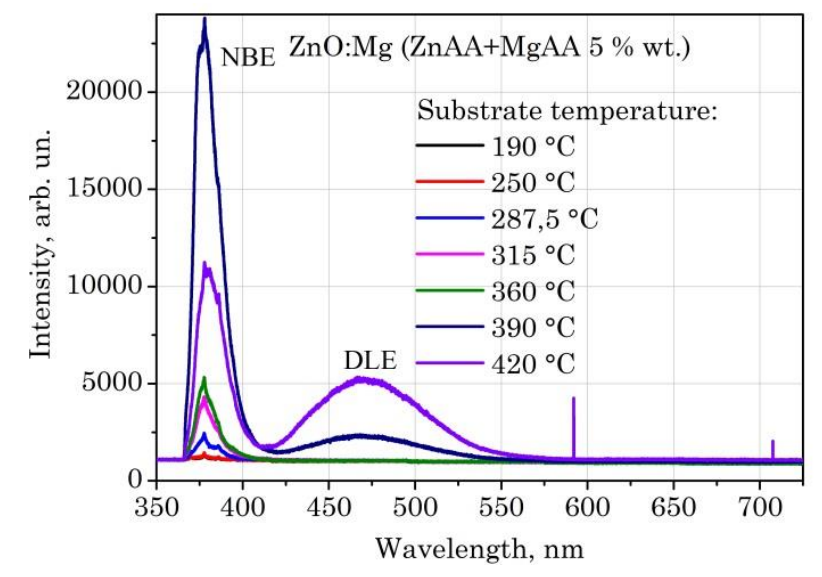

Fig. 4 - PL spectra of $\mathrm{ZnO}: \mathrm{Mg}(\mathrm{ZnAA}+\mathrm{MgAA} 5$ wt. \%) films obtained in the temperature range $190-420^{\circ} \mathrm{C}$

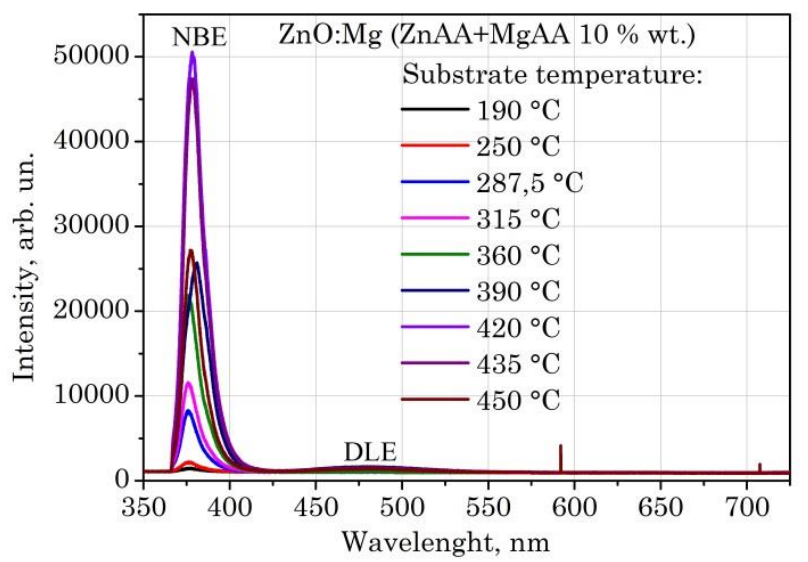

Fig. 5 - PL spectra of $\mathrm{ZnO}: \mathrm{Mg}(\mathrm{ZnAA}+\mathrm{MgAA} 10$ wt. \%) films obtained in the temperature range $190-450{ }^{\circ} \mathrm{C}$

We reconstruct one of the $\mathrm{ZnO}: \mathrm{Mg}(\mathrm{ZnAA}+\mathrm{MgAA}$ 10 wt. \%) PL spectra in the coordinates of the semilogarithmic dependence of the emission intensity on energy (Fig. 6). Only the dominant peak of marginal 
emission can be clearly observed in our sample, while the blurred maximum of the defective emission is still visible, for clarity it is depicted with a 10 -fold increase in intensity (green curve in Fig. 6). The obtained film is considered to have high quality crystallites.

With the introduction of $\sim 10 \mathrm{wt} . \% \mathrm{Mg}$, the band gap can be increased by $\sim 0.1-0.2 \mathrm{eV}$, and this should cause a blue shift of the maximum peak of NBE (see Fig. 6) when measuring PL at low temperatures [5]. It is known that the marginal emission depends on the temperature and can decrease from $\sim 3.36 \mathrm{eV}$ at $4 \mathrm{~K}$ to $3.28 \mathrm{eV}$ at RT for undoped zinc oxide [21]. It was initially expected that doping with $10 \mathrm{wt} \% \mathrm{Mg}$ would cause a significant blue shift of the edge emission band in the PL spectra. However, we have a blue shift of marginal emission of only $0.02 \mathrm{eV}$. It should be noted that a small size of nanostructures can cause a red shift of the maximum edge emission, compensating for the effect of magnesium [21]. Moreover, phonon replicas of free excitons are also responsible for the red shift of the main peak position.

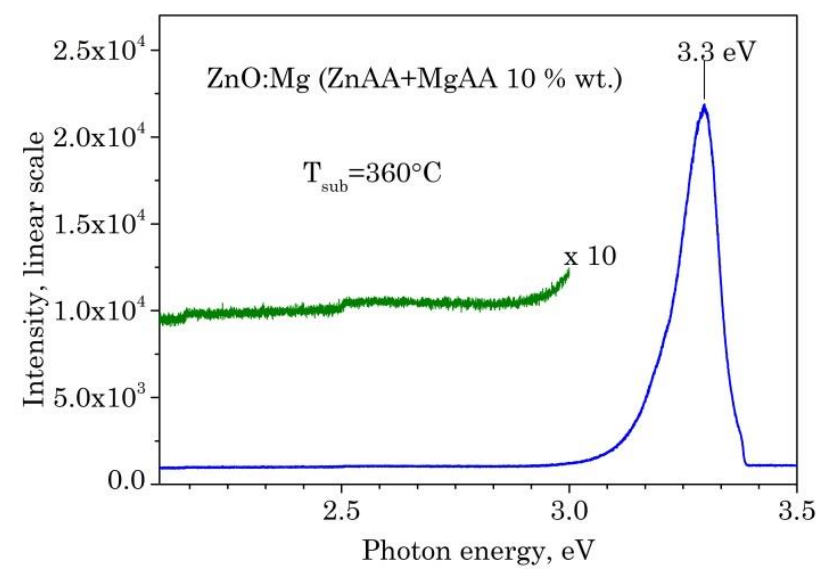

Fig. 6 - PL spectrum of $\mathrm{ZnO}: \mathrm{Mg}(\mathrm{ZnAA}+\mathrm{MgAA} 10$ wt. \%)

\section{REFERENCES}

1. H.M.Ü. Özgür, Ya.I. Alivov, C. Liu, A. Teke, M.A. Reshchikov, S. Doğan, V. Avrutin, S.-J. Cho, J. Appl. Phys. 98, 041301 (2005).

2. P. Zu, Z.K. Tang, G.K.L. Wong, M. Kawasaki, A. Ohtomo, H. Koinuma, and Y. Segawa, Solid State Commun. 103, 459 (1997).

3. P. Lianos, J. Hazard. Mater. 185, 575 (2011).

4. C.H. Ahn, Y.Y. Kim, D.C. Kim, S.K. Mohanta, H.K. Cho, J. Appl. Phys. 105, 1 (2009).

5. T. Gruber, C. Kirchner, R. Kling, F. Reuss, A. Waag, Appl. Phys. Lett. 84, 5359 (2004).

6. A. Ohtomo, M. Kawasaki, T. Koida, K. Masubuchi, H. Koinuma, Y. Sakurai, Y. Yoshida, T. Yasuda, Y. Segawa, Appl. Phys. Lett. 72, 2466 (1998).

7. S.Y. Hu, W.C. Chou, Y.H. Weng, J. Alloys Compd. 636, 81 (2015).

8. Y.N. Hou, Z.X. Mei, H.L. Liang, D.Q. Ye, C.Z. Gu, X.L. Du, Appl. Phys. Lett. 102, 263501 (2013).

9. X. Wang, K. Saito, T. Tanaka, M. Nishio, T. Nagaoka, M. Arita, Q. Guo, Appl. Phys. Lett. 107, 022111 (2015).

10. D. Thapa, J. Huso, H. Che, M. Huso, J.L. Morrison, D. Gutierrez, M. Grant Norton, L. Bergman, Appl. Phys. Lett. 102, 191902 (2013).
Briefly, the high-intensity NBE peak at $\sim 376 \mathrm{~nm}$ caused by free exciton recombination has the peak full width at half maximum of about $14.41 \mathrm{~nm}$. The emission band in the visible wavelength range (peak at $\sim 470 \mathrm{~nm}$ ) arises from radiative recombination through point defects in the $\mathrm{ZnO}$ lattice. The ratio of the peaks of NBE and DLE spectral integral intensity emission (figure of merit) was about 6, confirming that $\mathrm{ZnO}: \mathrm{Mg}$ nanostructures are suitable for LED applications.

\section{CONCLUSIONS}

The method of atmospheric pressure chemical vapor deposition for obtaining nanostructures of zinc oxide of different morphology is presented. From SEM images, we can conclude that in order to synthesize quasi aligned $\mathrm{ZnO}$ nanorods via APMOCVD on Si substrates, a substrate temperature between 400 and $500{ }^{\circ} \mathrm{C}$ is required. Lower $\mathrm{Si}$ substrate temperatures result in amorphous or polycrystalline thin films.

From the PL spectra, it is revealed that the use of 10 wt. \% MgAA (instead of 5 wt. \%) leads to an increase in the NBE intensity and suppression of DLE in the luminescence of $\mathrm{ZnO}$ nanostructures.

Magnesium acts as an isoelectronic impurity and leads to an increase in grain size (improving crystalline perfection) and improvement in NBE PL emission due to gettering of defects.

\section{ACKNOWLEDGEMENTS}

This work was partially supported by the research projects of the NAS of Ukraine "The development of photocatalytic nanocomposites for viruses inactivation in the air" (№ 40/20-H) and "Development of innovative photocatalytic nanostructured materials based on $\mathrm{ZnO}$ and $\mathrm{TiO}_{2} "(528 / \mathrm{IPM}-11 / 20)$.

11. H.-Y. Lee, W.-H. Tsai, Y.-C. Lin, C.-T. Lee, J. Vac. Sci. Technol. B, Nanotechnol. Microelectron. Mater. Process. Meas. Phenom. 34, 051207 (2016).

12. S. Maity, P.P. Sahu, C.T. Bhunia, IEEE Sens. J. 18, 6569 (2018).

13. S. Chawla, K. Jayanthi, H. Chander, Phys. Status Solidi Appl. Mater. Sci. 205, 271 (2008).

14. Q. Zhang, X. Gu, Q. Zhang, J. Jiang, X. Jin, F. Li, Z. Chen, F. Zhao, Q. Li, Opt. Mater. Express 8, 909 (2018).

15. N. Winkler, R.A. Wibowo, W. Kautek, T. Dimopoulos, J. Mater. Chem. C 7, 3889 (2019).

16. C.Y. Liu, B.P. Zhang, N.T. Binh, K. Wakatsuki, Y. Segawa, J. Cryst. Growth 290, 314 (2006).

17. B. Ahmmad, K. Kanomata, F. Hirose, Appl. Mech. Mater. 492, 311 (2014).

18. T. Onuma, M. Ono, K. Ishii, K. Kaneko, T. Yamaguchi, S. Fujita, T. Honda, Appl. Phys. Lett. 113, 132105 (2018).

19. D.M. Freik, Y.S. Yavorskiy, I.S. Bylina, P.M. Lytvyn, I.M. Lishchynskiy, V.B. Marusyak, Phys. Chem. Solid State 13, 934 (2012).

20. Q.X. Zhao, P. Klason, M. Willander, H.M. Zhong, W. Lu, J.H. Yang, Appl. Phys. Lett. 87, 211912 (2005).

21. Y. Gong, T. Andelman, G.F. Neumark, S. O'Brien, I.L. Kuskovsky, Nanoscale Res. Lett. 2, 297 (2007). 


\title{
Вплив температури підкладки і вмісту магнію на розвиток морфології та люмінесценцію плівок $\mathrm{ZnO}: \mathrm{Mg}$
}

\author{
Д.В. Миронюк, Л.А. Миронюк, В.А. Карпина, Л.І. Петросян, А.І. Свтушенко \\ Інститут проблем матеріалознавства імені І.М. Францевича НАН України, вул. Кржижановського, 3, \\ 03142 Київ, Україна
}

\begin{abstract}
У роботі наведено результати досліджень методами сканувальної електронної мікроскопії і фотолюмінесценції (ФЛ) особливостей мікроструктури та випромінювальних переходів плівок $\mathrm{ZnO}: \mathrm{Mg}$, отриманих методом хімічного осадження з парової фази металорганічних сполук при атмосферному тиску на підкладки кремнію. Різноманітні мікроструктури $\mathrm{ZnO}$ від полікристалічних плівок з гладкою морфологією до стовпщів та гексагональних стержнів ефективно утворюються в широкому діапа зоні температур $190-450{ }^{\circ} \mathrm{C}$ з використанням двох композицій суміші ацетилацетонатів цинку і магнію (ZnAA та MgAA) (5 та 10 ваг. \%) в якості прекурсорів. Температура підкладки має суттевий вплив на кристалічність та морфологію плівок $\mathrm{ZnO}$. Структури $\mathrm{ZnO}$ у формі колон утворюються при температурах вище $350{ }^{\circ} \mathrm{C}$. Вміст MgAA у суміші прекурсорів також впливае на морфологію частинок. При вмісті MgAA 10 ваг. \%, при низьких температурах підкладки $\left(200-320^{\circ} \mathrm{C}\right)$ утворюються зерна більших розмірів порівняно з ростом зерен у плівках при MgAA 5 ваг. \%, тоді як при вищих температурах підкладок $\left(350-450{ }^{\circ} \mathrm{C}\right)$ утворюються стержнеподібні структури. Швидкість росту структур ZnO зростае із збільшенням температури підкладки. У спектрах емісії ФЛ зразків з 10 ваг. \% MgAA (у порівнянні з 5 ваг. \%) спостерігаеться ріст інтенсивності крайової смуги та пригнічуеться випромінювання дефектних рівнів люмінесценції структур $\mathrm{ZnO}$. Тому можна зробити висновок, що магній діє як ізоелектронна домішка і приводить до покращення крайової емісії люмінесценції за рахунок гетерування дефектів. Магній також спричиняе збільшення розміру зерен, покращуючи досконалість кристалітів полікристалічних плівок ZnO:Mg, вирощених при низькій температурі підкладки, а також сприяе росту гексагональних стержнів при більш високих температурах підкладки. Структури оксиду цинку, леговані магніем, можуть виступати як ефективні фотокаталізатори.
\end{abstract}

Ключові слова: Метод хімічного осадження з парової фази металорганічних сполук при атмосферному тиску, Ацетилацетонат цинку, Ацетилацетонат магнію, Скануюча електронна мікроскопія, Фотолюмінесценція. 